\title{
Edukacja polonistyczna. Zderzenie z cywilizacją - uwagi wstępne
}

\section{Education in Polish Studies. A Clash with Civilization - Preliminary Remarks}

Bywały epoki, gdy wokół edukacji panował konsensus i nie odczuwano potrzeby jakiejkolwiek przebudowy. Bywały jednak i takie, gdy edukacja stawała się przedmiotem sporu, bo zmiany światopoglądu czy mentalności zmuszały do poszukiwania nowych sposobów przekazywania młodym ludziom doświadczenia pokoleń. W takiej epoce właśnie żyjemy. Podejmowane w Polsce reformy edukacji, radykalne decyzje, ich odwracanie, ponowne zwroty wynikają z niepewności, która nam obecnie stale towarzyszy. Jest to niepewność cywilizacyjna, znamienna nie tylko dla naszego kraju, ale i bez mała dla całego globu.

W czwartym zeszycie „Kontekstów Kultury” proponujemy podjęcie refleksji nad przyczynami tej niepewności i jej skutkami. Chodzi nam o przemyślenie sytuacji kulturowej, w której się znajdujemy. Jak kształcić, przekazywać wiedzę i umiejętności, kształtować postawy, gdy świat bardzo szybko się zmienia, wahamy się co do wartości, nie jesteśmy zgodni w kwestii priorytetów edukacyjnych? Choć decyzje polityczne stanowią oczywiste i niemożliwe do zignorowania tło, zależy nam na pogłębionej analizie obecnej sytuacji cywilizacyjnej i wynikających z niej możliwych rozwiązań edukacyjnych.

Punktem wyjścia, który proponujemy, jest dyskusja redakcyjna pomiędzy Ingą Iwasiów, Anną Janus-Sitarz i Piotrem Śliwińskim. Został w niej zarysowany obraz polskiej szkoły i kontekstu, w jakim funkcjonuje. Są tu przedstawione wyzwania cywilizacyjne, fetysze, lęki. Zarazem bardzo konkretne problemy, takie jak płace nauczycielskie i status społeczny nauczyciela. Rozmówcy wskazują perspektywy rozwoju szkoły przygotowującej do życia ludzi samodzielnie myślących, nieobawiających się trudności intelektualnych, którzy w swoich poszukiwaniach nie zawsze dochodzą do konkluzji, ale znają drogę wiodącą do rozstrzygania problemów, budują wspólnotę rozumiejących się osób. 
Autorzy zamieszczonych w dalszej części numeru artykułów wychodzą z pozycji diagnostów i opisują stan współczesnego społeczeństwa, a zwłaszcza człowieka stojącego przed wyzwaniem, jakim jest szybko zmieniający się świat. Nie poprzestają jednak na diagnozie. Ukazują różne drogi, którymi może podążać nowoczesna edukacja, proponują rozwiązania oparte na współczesnej refleksji dydaktycznej i praktyce.

Krzysztof Koc, odwołując się do myśli Marthy C. Nussbaum i Chantal Delsol, analizuje sytuację kulturową, w której prowadzimy edukację humanistyczną. Istotną cechą współczesnej cywilizacji jest różnorodność, może ona inspirować, ale może też budzić odczucia niepokoju, zagubienia, a nawet utraty tożsamości. Nussbaum w humanistyce, a zwłaszcza literaturze, znajduje szansę na „oswajanie różnic”. Delsol pisze o etyce troski. Obie myślicielki wskazują, że edukacja musi służyć „nauce dociekliwości” (Nussbaum) czy „afirmacji inicjatywy” (Delsol). Autor zwraca uwagę, że zmiany w polskiej edukacji zmierzają w odwrotnym kierunku, raczej odpowiadają temu, co Vaclav Havel opisywał jako edukację posttotalitarną. Stawia pytanie, na jakiej szkole powinno nam zależeć.

Dariusz Szczukowski patrzy na szkołę z perspektywy pedagogiki postkrytycznej. Przypomina, że według etymologii greckiej szkoła to „czas wolny”, wolny od zewnętrznych powinności (rynkowych, politycznych), a pozwalający się skupić na bezinteresownym poznaniu, uważności, lekturze służącej budowaniu relacji. W takiej perspektywie autor krytycznie ocenia zmiany w polskiej edukacji, które zakładają, że szkoła ma być głównie pasem transmisyjnym do przekazywania gotowej i ustalonej wiedzy. Mimo to zmierza do pozytywnej konkluzji i wskazuje, że nauczyciel może przekroczyć zewnętrzne uwarunkowania, by uczyć lektury nastawionej na „tak” wobec życia.

Marta Rusek skupia się na podstawowym problemie edukacji polonistycznej, czyli kryzysie czytelnictwa. Ujmuje go w szerokim kontekście historycznym, pokazuje, że nie jest to zjawisko wcześniej nieznane, jakkolwiek współcześnie zyskało ono nowy i niepokojąco głęboki wymiar. Koncentruje się na roli szkoły, która niepokoi, gdy nie tylko narzuca lektury trudne w odbiorze, niekiedy już na poziomie językowym, ale i uczy uproszczonych interpretacji. Autorka upomina się o podmiotowe zaangażowanie uczniów w akt czytania. Prezentuje propozycje różnych rozwiązań dydaktycznych, które mogłyby temu służyć.

W podobnym duchu pisze Kinga Białek. I ona wychodzi od diagnozy. Szkoła powinna przygotowywać do świadomej aktywności w życiu publicznym, niestety w skali globalnej w niewielkim stopniu wywiązuje się z tego zadania, nie niweluje różnic społecznych, ale wielokrotnie je utrwala, a nawet pogłębia. Znajduje to wyraz w bezradności systemów edukacyjnych w kształceniu umiejętności krytycznego czytania tekstów. Autorka skupia uwagę na nauczaniu rozumienia tekstów argumentacyjnych, z jakimi człowiek najczęściej się spotyka. Przedstawia formy dydaktyczne, sprawdzone w praktyce, które mogą temu skutecznie służyć. 
Lekturze szkolnej poświęca swój artykuł Paweł Sporek. Wychodzi od koncepcji „wspólnot interpretacyjnych” Stanleya Fisha. Takie wspólnoty skutecznie tworzy szkoła, która narzuca interpretacje literatury, zostawiając niewiele miejsca na lekturę jako „proces stwarzania tekstu na nowo”. Rezultatami są uproszczone odczytania dzieł i będąca ich skutkiem niechęć do literatury. Autor jako remedium proponuje otwarcie na uczniowskie wspólnoty interpretacyjne. One mogą się rodzić spontanicznie, niekiedy już się tworzą w przestrzeni medialnej. Celem jest indywidualne, niepowtarzalne przeżycie lektury, jakim można się podzielić z tymi, którzy przeżywają podobnie. Ceną jednak będzie rezygnacja z wielu aspektów nauczania wiedzy o literaturze i jej akademickiej analizy.

Karolina Starnawska dostrzega problem w oderwaniu uczniów w szkole od natury i fizycznej aktywności. Zarówno dominacja mediów cyfrowych w życiu młodych ludzi, jak i tradycyjna szkoła sadzająca ich w ławkach powodują, że zostają oni odizolowani od zewnętrznego świata. Autorka postuluje, żeby wykorzystać literaturę do nauki wrażliwości na naturę. Przedstawia propozycję lektury Tajemniczego ogrodu jako utworu, który pozwoli dzieciom na dostrzeżenie urody rzeczywistości poza budynkiem szkoły. Zachęca, żeby przy omawianiu tej pozycji wychodzić z klasy i obserwować przyrodę.

$\mathrm{Na}$ koniec proponujemy dwie recenzje niezwiązane już z głównym tematem zeszytu. Agnieszka Morstin omawia książkę Krisa Van Heuckeloma Polish Migrants in European Film 1918-2017. Belgijski badacz ukazał przemiany filmowego obrazu Polaków migrujących do Europy Zachodniej. Co zaskakujące, bo rzadko zdajmy sobie z tego sprawę, ów obraz pojawia się w kinie europejskim dosyć często. Przybywający na Zachód Polak ukazywany jest z reguły jako „close Other”, bliski obcy. Z kolei Elżbieta Dutka recenzuje książkę Karla Schlögla, Odkrywanie nowoczesnej Europy - próba archeologii. Ten zbiór szkiców niemieckiego historyka stanowi próbę zrozumienia przeszłości i teraźniejszości Europy przez analizę śladów czasu minionego w różnych miastach kontynentu, zwłaszcza jego wschodniej części.

Krzysztof Biedrzycki Redaktor prowadzacy zeszytu 